\title{
Editorial - Theory building in marketing: rationalizing South Asian perspective
}

The ever-changing dynamic world is full of opportunities and challenges. Globalization of markets seems like a dream on the verge of recent developments such as COVID-19. Another essential perspective is cultural dynamism, which is strengthening over time. Once theorized as a global consumer, culture is now also understood as a local consumer culture. Pragmatically, international brands are trying hard to launch more local culture-friendly brand campaigns in response to rising local consumer culture trends. Global events such as shooting in Christchurch, New Zealand, massacre in Colombo Sri Lanka, War in the Middle East and even British Brexit are reshaping how theorists conceived globalization of markets decades ago. The continuous progress of regional and local brands, accustomed to serving the needs of individuals belonging to a particular culture, adds more challenge to understand new forms of brand globalism. Nationalistic campaigns of governments to promote local trade and business are yet another challenge to the fore. Thus, it requires a better understanding of different cultures so that successful marketing programs can be initiated and implemented.

South Asia is home to one of the world's earliest known civilizations, i.e. the Indus civilization. That day, it is one of the most densely populated regions on the planet and includes Sri Lanka, India, Pakistan, Bangladesh, Bhutan, Nepal, Afghanistan and the Maldives. Due to the distinct characteristics of all the countries in the region, South Asia is eye candy for business organizations, social activists, policymakers, politicians, educational enthusiasts, media, entertainment and agriculture. Contrarily, the rising middle class with attractive financial pockets, colossal population, friendly people, and several social and political issues demand customized marketing strategies.

The majority of the population in South Asia lives in rural areas and depends on agriculture as a significant source of income and employment (Sharma et al., 2019). Historically, marketing as an activity in South Asia was performed by agriculturalists. As economies and competition grew, they started promoting their products to consumer segments having some choices. However, South Asian economies have recently observed a rapid change in consumer lifestyle, which requires a shift in consumer culture positioning approaches used by marketers. The socio-demographic and political trends such as urbanization, materialism, economic turmoil, radical changes in political systems, traffic issues and a rapid decline in population growth are few challenges that require thoughtful research in the field of sociology of these markets.

South Asia paradoxically is both a rich and a poor region due to the mismatch in the education levels, economic instability, rural-urban divide, i.e. opportunities and capacities available to the population living in different states of the region (Qayyum et al., 2021). It is a region where people across borders are culturally and socially interrelated (Tripathi and Chaturvedi, 2020). An area of

(C) N.J. Dewasiri, Sudhir Rana and Muhammad Kashif. Published in South Asian Journal of Marketing. Published by Emerald Publishing Limited. This article is published under the Creative Commons Attribution (CCBY 4.0) licence. Anyone may reproduce, distribute, translate and create derivative works of this article (for both commercial and non-commercial purposes), subject to full attribution to the original publication and authors. The full terms of this licence may be seen at http://creativecommons. org/licences/by/4.0/legalcode

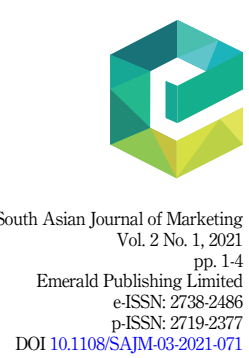


SAJM

2,1

2 contrasts is marked by optimism as well as pessimism and features many intricacies. Despite income disparities, poverty, contentious politics, social pluralism, natural disasters and many other reasons, South Asia continues to grow and is a hub of labor-intensive manufacturers and service centers. To understand the region's importance for marketing scholars and practitioners, let us scan through business and economics, socio-political-cultural, education and research, media and entertainment and other miscellaneous lenses.

\section{Business and economic (what makes a business function)}

Prospects of an economic rebound in South Asia are firming up as growth is set to increase by $7.2 \%$ in 2021 and $4.4 \%$ in 2022, climbing from historic lows in 2020 and putting the region on a path to recovery (World Bank, 2021). It is expected a gradual decline in poverty while exports of goods are being recovered. Accordingly, the further developed local financial viewpoint results from South Asian nations' endeavors to monitor their COVID-19 caseload and quickly carry out antibody crusades. Be that as it may, the recuperation stays delicate since the pandemic is not taken care of, and the immunization is on the advancement. Numerous organizations need to compensate for lost income. A great many specialists, a large portion of them in the casual area, actually falter from employment misfortunes, falling earnings, deteriorating imbalances and human resources shortfalls. Nations reliant upon the travel industry, particularly Bhutan, Sri Lanka, Maldives and Nepal, were vigorously influenced by the emergency as their travel industry area could take more than completely recuperate (World Bank, 2021). Further, debt sustainability is in danger as certain nations have become more defenseless against outside shocks, especially the Maldives and Sri Lanka. Hence, the marketing applications/practices of the South Asian countries are different from the other regions to suit the current economic outlook of the region.

\section{Socio-political-cultural (what influence consumer behavior)}

Several studies aim to explore why South Asian consumers are different so that companies can win over their hearts and minds. Most of these studies consider samples from one or a few countries together. But is it not interesting to understand how this continent manages the expectations of a large population that lies at the bottom of the economic pyramid? What ties them together as a unity in diversity? One of the essential aspects is concerning nationalism in South Asia, and it has been different from the west has also been an important issue. In recent decades there have been deviations in the form and contents of nationalism in South Asia, leading to the trends of sub-nationalism and secessionism. Nationalism has obtained different shapes and expressions in South Asian countries, such as secular nationalism, lingua-cultural nationalism, religious nationalism, linguistic nationalism, aggressive nationalism, etc. (Upreti, 2006).

Interestingly, South Asia is the only sub-continent in the world where one can experience true diversity. This market often is labeled as an untapped market. This region is famous for its religions, culture, rituals and customs, ethics, natural resources, intensive and skilled labor and, most importantly, growth potential. Contemporary South Asia has covered a long and exciting journey from orthodox to postmodern. A visible change is reflected through various aspects of living standards and style. The journey looks like different continents of peoples' lives, such as religion equality to religion autonomy; gender equality to gender autonomy; people celebrate any culture, and it is the world's populous democracy. It symbolizes that every business organization has a chance to tap this market. And, it can be successfully achieved if the characteristics of this region are fully understood.

Finally, South Asia's rich history, culture and folklore have not been explored up to its true potential. Frequent socio-cultural events to signal togetherness, rich music to orchestrate voices and rhythms, superstitious beliefs and religious diversity, authoritative yet self-less parenthood, spiritually enriching writings of saints and poets, and grandma 
stories invite scholars to explore this region in an effort to stretch epistemological boundaries of marketing.

We are indeed pleased to introduce the first issue of Volume Two in collaboration with Emerald publishing. We most respectfully dedicate this issue to the late Professor Uditha Liyanage with extreme regard. Professor Liyanage was a hon. fellow member of the Sri Lanka Institute of Marketing (SLIM), a Chartered Marketer and a fellow of the Chartered Institute of Marketing (CIM) and also served as the director and professor at the Postgraduate Institute of Management (PIM), University of Sri Jayewardenepura. Professor Uditha Liyanage rendered an invaluable contribution to the development of the marketing profession and the elevation of the marketing fraternity in South Asia.

This issue includes five original research contributions across marketing domains and countries. The diversity and contributions included in the issue also address that scholars from any part of the world are welcome to submit their research contributions. We are opening the issue with a significant contribution by Salim Moussa on "Contamination by citations: references to predatory journals in the peer-reviewed marketing literature." The objective of this contribution is to spread awareness on citation contamination. This study aims to investigate the extent of citation contamination in the peer-reviewed marketing literature. The second contribution, "Trust and product as moderators in online shopping behavior: evidence from India" is by Felicita Davis, Manoj Britto Francis Gnanasekar and Satyanarayana Parayitam. This study examines the antecedents of online shopping user behavior and customer satisfaction to provide new insights into the importance of gaining trust in influencing consumer behavior. The following contribution in this queue is by Rekha Dahiya, Dimpy Sachar on "Discriminant analysis application to understand the usage of digital channels while buying a car." The study reveals that car buyers are making ample usage of digital channels wherein the website is the most used digital channel and smartphones are the most used digital devices used by car buyers. Forth contribution, "Users' attitude and intention to use mobile financial services in Bangladesh: an empirical study" is by Md. Tanvir Alam Himel, Shahrin Ashraf, Tauhid Ahmed Bappy, Md Tanaz Abir, Md Khaled Morshed and Md. Nazmul Hossain. In this study, the authors investigate customers' attitudes and intentions to adopt mobile financial services (MFS) and explore determinants and consequences of attitude toward using MFS. The last contribution included in this issue is on "Impacts of Binge-Watching on Netflix during the COVID-19 pandemic" by Kazi Turin Rahman, Md. Zahir Uddin Arif. This study investigates motivational factors, media consumption and negative attributes associated with binge-watching on Netflix during the COVID-19 outbreak.

We are thankful to authors, reviewers and publishing counterparts for their continued collaboration to make this issue exciting and apt to the aims and scope of the South Asian Journal of Marketing (SAJM). Feel free to share your feedback and suggestions with any of the editors.

\section{N.J. Dewasiri, Sudhir Rana and Muhammad Kashif}

\section{References}

Qayyum, U., Sabir, S. and Anjum, S. (2021), "Urbanization, informal economy, and ecological footprint quality in South Asia”, Environmental Science and Pollution Research. doi: 10.1007/s11356-02115111-x.

Sharma, V.P., De, S. and Jain, D. (2019), "Managing agricultural commercialisation for inclusive growth in South Asia”, Gates Open Research, Vol. 3, pp. 1-46. 
SAJM

2,1

4
Tripathi, D. and Chaturvedi, S. (2020), "South Asia: boundaries, borders and beyond", Journal of Borderlands Studies, Vol. 35 No. 2, pp. 173-187.

Upreti, B. (2006), "Nationalism in South Asia: trends and interpretations", The Indian Journal of Political Science, Vol. 67 No. 3, pp. 535-544.

World Bank (2021), South Asia Economic Focus, Washington, available at: https://www.worldbank. org/en/region/sar/publication/south-asia-vaccinates-south-asia-economic-focus-spring-2021. 